\title{
Bauxite Deposits of the
}

Margerum District

Alabama

GEOLOGICAL SURVET BULLETIN 1199-D 


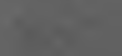

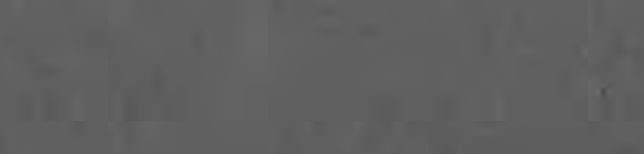

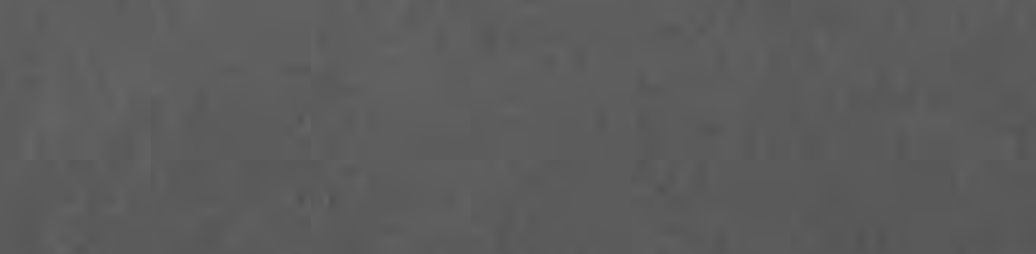

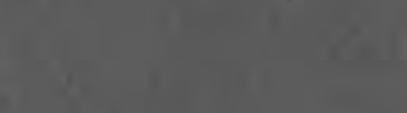$$
x^{2}-1
$$

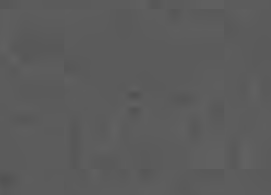




\section{Bauxite Deposits of the}

Margerum District

\section{Alabama}

By HARLAN R. BERGQUIST and ELIZABETH F. OVERSTREET

BAUXITE DEPOSITS OF THE SOUTHEASTERN UNITED STATES

GEOLOGICAL SURVEY BULLETIN 1199-D

Distribution and occurrence

of bauxite and related clay

deposits

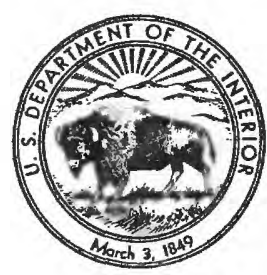




\section{UNITED STATES DEPARTMENT OF THE INTERIOR}

STEWART L. UDALL, Secretary

\section{GEOLOGICAL SURVEY}

Thomas B. Nolan, Director 


\section{CONTENTS}

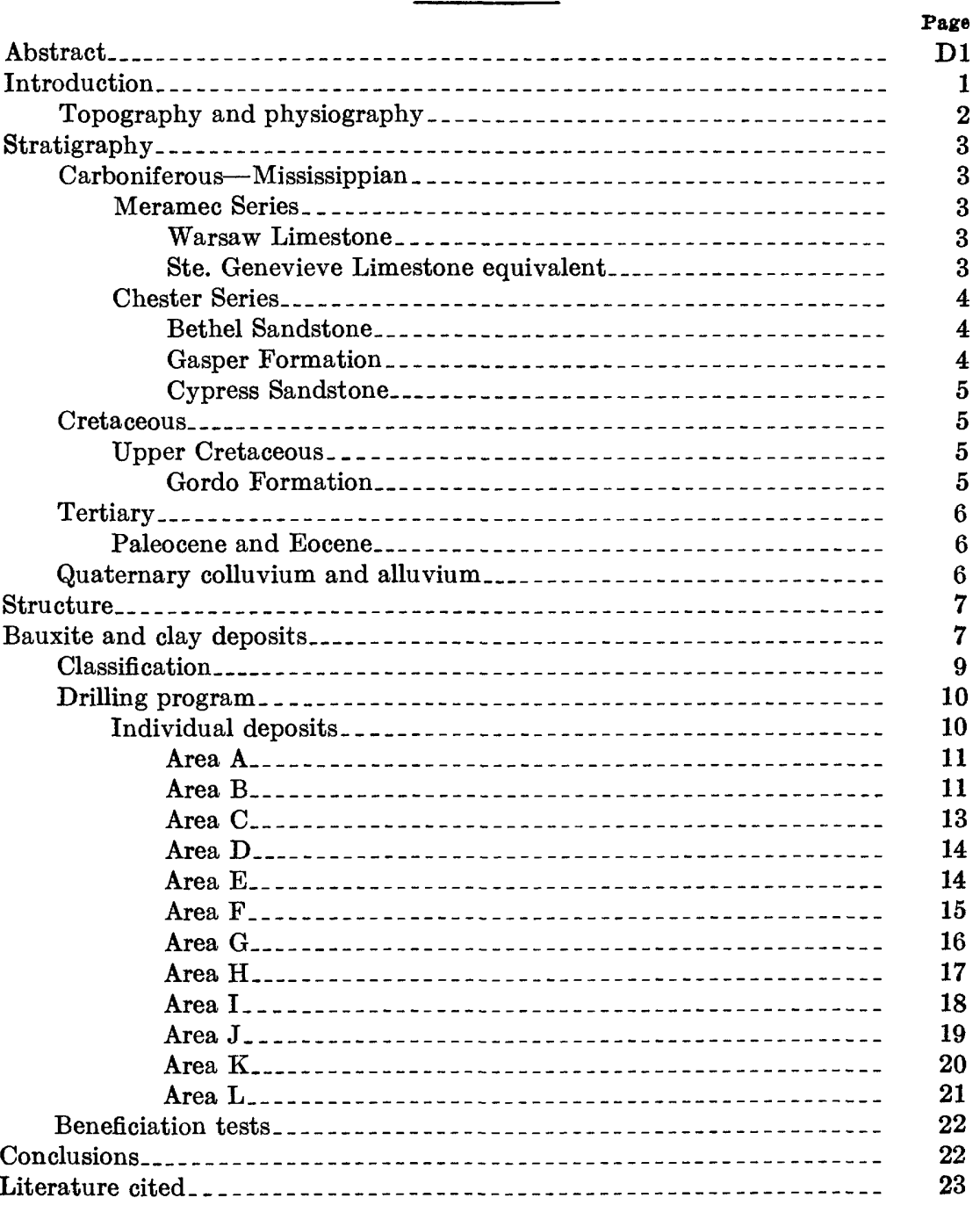




\section{ILLUSTRATIONS}

[Plates are in pocket]

Plate 1. Geologic map of the Margerum bauxite district.

2. Generalized geologic map.

3. Isopach maps and sections of bauxite and kaolin deposits in areas $\mathbf{C}$, $\mathbf{E}, \mathbf{G}, \mathbf{H}$, and $\mathrm{I}$. 


\title{
BAUXITE DEPOSITS OF THE SOUTHEASTERN UNITED STATES
}

\section{BAUXITE DEPOSITS OF THE MARGERUM DISTRICT, ALABAMA}

\author{
By Harlan R. Bergquist and Elizabeth F. Overstreet
}

\begin{abstract}
The Margerum bauxite district, in northwestern Colbert County, northwestern Alabama, is about 5 miles long and about 3 miles wide. The bauxite and kaolin are in small pockets and lenses in the top of the Gordo Formation of Late Cretaceous age. The Gordo unconformably overlies structurally deformed limestone, sandstone, and shale beds of Mississippian age. The bauxite is of small extent, and most is low grade, high in silica but low in iron. Some of the silica is in the form of free quartz sand which can be removed by beneficiation, but most is present as clay minerals. The deposits vary considerably in composition over short distances and commonly range from bauxite to kaolin to silty or sandy clay within a few feet. A joint drilling program of the U.S. Bureau of Mines and U.S. Geological Survey demonstrated the extremely small size of the deposits. They are estimated to have a total reserve of about 100,000 tons of at least grade $D$ bauxite and 30,000 tons of slightly sandy kaolinitic clay. The highest grade material found was grade $\mathrm{C}$ bauxite, which constitutes less than 5 percent of the total bauxite in the district.
\end{abstract}

\section{INTRODUCTION}

The Margerum bauxite district is a small area about 5 miles long and about 3 miles wide lying south of Margerum, a small town in the northwestern part of Colbert County, Ala. (pl. 1). The district is one of several which lie north of the present Coastal Plain and in which bauxite is associated with unconsolidated sediments of Late Cretaceous age.

The first discovery of bauxite in the district was by J. W. Adams, a prospector, who, in 1921, found a small deposit of high-iron bauxite in a highway cut a quarter of a mile south of Margerum. He later extended his search for ore bodies into the hills on both sides of Bear Creek and to the west into Tishomingo County, Miss. Adams dug 75 
pits and shallow trenches in the region. Pisolitic material was found in 46 of them, irregularly distributed within an area of about 100 acres in secs. $13,14,23$, and 24, T. 4 S., R. $15 \mathrm{~W}$. The pisolitic clay in many of these pits was sandy and low in alumina, but others contained pisolitic kaolin and bauxite. The tract of land on which the deposits were found was acquired by the Alabama Bauxite Co. a few years later but was never developed. Adams recognized the general geologic setting of the deposits and, therefore, confined his prospecting to the Tuscaloosa Formation (now Gordo Formation of the Tuscaloosa Group).

Adams did not publish the results of his work, but the district was mentioned briefly by E. F. Burchard and has been described in some detail by Walter B. Jones. Burchard (1925, p. 101) suggested that the bauxite was in the underlying Mississippian limestones in erosion channels and sinkholes which had been partly filled by Tuscaloosa sediments. Studies by Jones (1926, p. 795-798; 1929, p. 24-36; 1940, p. 78-94) included stratigraphy of the district, a description of the bauxite and its mode of occurrence, and brief logs, together with analyses of samples from most of Adam's prospect pits.

In 1942, the senior writer made a reconnaissance of northwestern Colbert County to estimate the amount of bauxite that would be available in an emergency and to determine whether additional localities favorable for the occurrence of bauxite existed in the region. During November 1942, an area of about 15 square miles surrounding the known deposits was mapped in detail (pl. 1). A preliminary geologic map showing extent of the formations of Mississippian and Late Cretaceous age in the district and suggested drilling sites was released by the U.S. Geological Survey (Bergquist, 1943). During May, June, and July 1943 the area was prospected by a cooperative churn-drill program of the U.S. Bureau of Mines and the Geological Survey.

\section{TOPOGRAPHY AND PHYSIOGRAPHY}

The Margerum bauxite district is in the extreme southern part of the Highland Rim section of the Interior Low Plateau physiographic province (Fenneman, 1938, p. 414-427) close to its boundary with the Gulf Coastal Plain. The surface is a greatly dissected upland underlain by alternating beds of limestone, shale, and sandstone of Mississippian age; these rocks are partly covered by outliers and valley fill of sand and gravel of Cretaceous age. At many places this sand and gravel has crept down over the present valley walls as colluvium, obscuring the underlying formations. The altitude of the main divide east of the deposits is 700 to 800 feet, and local relief is around 200 feet. 


\section{STRATIGRAPHY}

Thin formations of limestone, shale, and sandstone of the Meramec and Chester Series of Mississippian age are exposed along the valleys (pl. 1). At most places they are obscured by almost flat-lying outliers of sand and gravel of the Gordo Formation of Late Cretaceous age that cap most of the hills and ridges. Colluvium from the Gordo Formation covers the lower slopes. Bauxite and kaolin occur as thin lenses or pods in the top of the Gordo Formation. All known lenses either crop out at the surface or are covered by a thin layer of colluvial sand and gravel. The lenses are considered to be of Paleocene or early Eocene age.

\section{CARBONIFEROUS-MISSISSIPPIAN}

MERAMEC SERIES

WARSAW LIMESTONE

The Warsaw Limestone, the oldest formation exposed in the area, is a massive cherty fossiliferous crystalline limestone, much jointed and cut by solution cavities. Caves and sinks have locally formed along solution channels, especially in the western part of the region where the Cretaceous beds have been largely removed. Two sinkholes were noted in secs. 11 and 14 east of Bear Creek, and there is an entrance to an unexplored cave in a low bluff south of a field near the center SW1/4 sec. 23, T. 4 S., R. 15 W. in Harris Hollow. Deep weathering of the limestone yields a reddish-brown soil containing irregular chert fragments.

Along Bear Creek west of Margerum, outside the mapped area, only a few feet of the Warsaw Limestone is exposed, but southward from the covered bridge over Bear Creek (NE1/4 sec. 10, T. 4 S., R. 15 W.), the limestone crops out fairly continuously east of the valley in the foothills. Approximately $31 / 2$ miles south of Margerum near the center sec. 14, T. 4 S., R. 15 W. (pl. 1) more than 60 feet of the limestone is exposed on a hillside forming the south wall of Calhoun Hollow and the east edge of the bottomlands of Bear Creek. The numerous other exposures of the Warsaw Limestone in nearby hollows are, for the most part, only along low bluffs or in the beds of streams.

\section{STE. GENEVIEVE LIMESTONE EQUIVALENT}

In western Colbert County the St. Louis Limestone is missing, and the Warsaw Limestone is directly overlain by about 60 feet of thinbedded fissile greenish-gray shale containing thin layers of limestone and sandstone. This shale is considered (Butts, 1926) the equivalent of the Ste. Genevieve Limestone which elsewhere is typically an oolitic limestone. In Colbert County the shale forms long slopes of weathered 
plastic tan or reddish-brown clay usually covered by vegetation and strewn with blocks of the overlying Bethel Sandstone. At the base of the shale is a thin bed of argillaceous limestone which is crowded with Productus inflatus McChesney and, being only a foot or two thick in the area mapped, is an excellent key horizon for structural mapping (pl. 1).

\section{CHESTER SERIES}

\section{BETHEL SANDSTONE}

A fine-grained gray to tan or brown mostly thin bedded somewhat fossiliferous sandstone, the Bethel Sandstone, overlies the Ste. Genevieve equivalent. At some places the formation forms low bluffs 10 to 15 feet high. Its maximum thickness is 25 feet (road grade near the center sec. 11, T. 4 S., R. 15 W.) in the western part of the district where the rock forms wide benches. Eastward within a distance of 2 miles, it thins to a few feet and is about 2 feet thick in the bottom of an old asphaltic limestone quarry near the middle W1/2 $\mathrm{SE} 1 / 4$ sec. $12, \mathrm{~T} .4$ S., R. 15 W. (pl. 1). At the top of the formation, a thin shale bed in most places separates the sandstone from limestone of the Gasper Formation above. At a few places in the district the Bethel Sandstone is impregnated with asphalt.

\section{GASPER FORMATION}

The Gasper Formation consists of two unnamed units : a basal limestone and a thick shale section containing one thin limestone bed. The basal limestone is a thick-bedded light-gray fossiliferous limestone that is in part oolitic and is locally so heavily impregnated with asphaltic material that the rock is quarried (sec. 1, T. 4 S., R. 15 W.) for road metal. At many places the oolitic limestone, a few feet to 10 or 15 feet thick, is the predominant rock and is associated with beds of fine-grained, in part cherty, limestone. At other places the fine-grained limestone predominates. The limestone unit of the Gasper has a maximum thickness of 20 to 25 feet in western Colbert County.

Overlying the basal limestone of the Gasper formation is 140 to 150 feet of gray-green shale that, about midway in the section, contains a thin limestone bed. This limestone, which is thinly bedded, shaly to sandy, and very fossiliferous, is rarely more than 8 or 10 feet thick but is persistently ledge forming on the long shale slopes and crops out in the heads of the hollows along the main divide. It is not exposed on the tips of the spurs along the western part of the area, where it has either been removed by erosion or is covered by Cretaceous rocks.

Certain fossils are fairly common in the limestone beds of the formation. The blastoid genus Pentremites is represented by several 
species which are abundant on the weathered slopes of the basal limestone; more rare are the plates of Talarocrinus sp. In the middle limestone bed, shells of the brachiopod Chonetes chesterensis Weller are extremely abundant, and a bryozoan, Archimides sp., is commonly found along the bedding planes of the rock, or weathered from it.

\section{CYPRESS SANDSTONE}

The Cypress Sandstone consists of massive to thinly bedded mediumto fine-grained tan or white sandstone which forms low bluffs and benches in the southeastern part of the district (secs. 19 and 30, T. 4 S., R. 14 W.) and particularly above the valley and tributaries of Little Buzzard Roost Creek (secs. 26 and 29, T. 4 S., R. 14 W.) west of the area shown on plate 1 . The maximum thickness of the formation in that area is about 20 to 25 feet. At the heads of the hollows along the divide within the area of plate 1 are remnants of the Cypress, but the formation seems to have been removed over most of the north half of the district, except along the hilltop east of the road in sec. 1, T. 4 S., R. $15 \mathrm{~W}$. Associated with the sandstone are sandy limestone beds which are not well enough exposed to reveal stratigraphic relations. Locally, chert gravels of the Gordo Formation are cemented to the surface of the limestone.

\section{Cretaceous \\ UPPER CRETACEOUS \\ GORDO FORMATION}

Continental deposits of sand, waterworn chert gravel, and some clay, derived almost entirely from the nearby Mississippian formations, were spread over a dissected land surface during Late Cretaceous time. These sediments constitute the Gordo Formation, which now rests unconformably on older formations in large areas of western Alabama and eastern Mississippi.

The Gordo deposits in the Margerum district are variable in thickness but probably do not exceed 125 feet, being outliers along the eroded margin of the formation, which thickens to the west and south. At many places in the district, much of the Gordo has been removed by erosion. The Gordo was deposited on an irregular land surface as indicated by outcrops of sandstone or limestone of Mississippian age high along hillsides, whereas nearby, where ancient valleys existed, it extends at least to the present level of Bear Creek valley, a fact indicating a relief of more than 100 feet on the surface of the Paleozoic rocks.

The formation is characteristically a mixture of sand and gravel, but locally gravel is the dominant material. A heary conglomerate consisting of gravel cemented by ironstone commonly forms irregular $757-5650-65-2$ 
benches and protects the hills from severe erosion; at many places a conglomerate forms the basal part of the formation.

\section{TERTIARY}

\section{PALEOCENE AND EOCENE}

Sandy clay and pisolitic kaolin and bauxite are present as thin lenses or pods in the top of the Gordo Formation. The clay and bauxite lenses are considered to be of early Tertiary age on the basis of their similarity to bauxite deposits which can be accurately dated in the Southeastern States. The lenses must be Late Cretaceous or younger as they have been found only in the top of the Gordo Formation, exposed at the present surface or buried by a few feet of sand and gravel, probably colluvial, or sandy soil. The pisolitic bauxite and kaolin are underlain by a relatively thicker sequence of finegrained brown sand, sandy or silty clay, thin beds of gravel, and some chert. Where data from drill holes are sufficient to show a lithologic sequence, the lenses of clay and bauxite plus the underlying sands appear to fill depressions in the Gordo Formation. The presence of numerous sinkholes in the district suggests that first the sands and then the clays and bauxite were deposited in ancient sinkholes. Whether the bauxite was formed before or after the parent material was deposited in sinkholes is a question that cannot be answered with the data at hand.

The upper surface of pisolitic material in some of the deposits is irregular (such as that in area G, p. 16, 17) and may sag in places as much as 50 feet. These "sags" are filled with sandy clays containing lignite fragments and are thus reminiscent of lignitic clays characteristic of the Wilcox Group of early Eocene age.

In the Margerum district, the rather meager data indicate that the bauxite and pisolitic kaolin deposits are Paleocene or Eocene in age or may represent minor parts of both.

\section{QUATERNARY COLLUVIUM AND ALLUVIUM}

Colluvium derived from the Gordo Formation obscures the Mississippian formations at many places and creates an illusion of a continuous heavy blanket of gravel over a great deal of the area, especially on the long shale slopes.

All valley bottoms are filled with alluvial sand and clay derived from the Mississippian deposits and the Cretaceous beds. At places this alluvial material is thin, and the Warsaw Limestone is exposed in stream beds. 


\section{STRUCTURE}

The regional dip of the Paleozoic rocks is southwest; but the deformation of the region has produced local folds, and some dips are at variance with the regional dip.

The structure contours on plate 1 were drawn on the basis of altitudes, determined by altimeter, on either the thin Productus inflatus bed at the base of the shale in the Ste. Genevieve equivalent or on the top of the Bethel Sandstone, 70 to 80 feet above that bed.

The scanty data suggest an anticlinal nose crossing the general area of the junction of Cripple Deer Creek and Bear Creek east of the mapped area in sec. 10, T. 4 S., R. 14 W. and extending into sec. 11. The north flank is relatively steep, whereas the south flank slopes gently. In sec. 11, the nose seems to swing to the southeast and continues across sec. 14 and into secs. 23 and 24 . In the east half of sec. 23, along McCluskey Hollow, the south end of the nose apparently collapsed by the formation of a sinkhole in the underlying Warsaw Limestone. Evidence of the sink is suggested from outcrops of a small patch of the Bethel Sandstone exposed along the north branch of McCluskey Hollow about 35 feet lower than outcrops along the south side of the main valley wall 1,000 to 2,000 feet to the south and southwest. Because caves are indigenous to the Warsaw Limestone, it is more probable that a sink underlies the area than that faulting has dropped a segment of the sandstone. This general area also has the greatest concentration of small lenses and pockets of bauxite and tends to confirm Burchard's suggestion (1925, p. 101) that the bauxitic clays accumulated in low places produced by erosion channels and sinkholes in the limestone of Mississippian age.

\section{BAUXITE AND CLAY DEPOSITS}

Bauxite in the Margerum district occurs as low-grade very small lenses or pockets in the top of the Gordo Formation at or near the present land surface. Deposits exposed at the surface have furnished considerable rather resistant pisolitic float which aided in their discovery. The combination of low grade and small size makes these deposits of no economic interest under conditions in the 1950's and. earlier. The possibility of discovering new and large deposits is considered to be remote.

All bauxite beds occupy the divides or upper slopes in the district. The tops of all but one of the deposits are at about the same altitude. This one is about 50 feet lower but is close to the present surface. No bauxite bodies were found under a heavy gravel overburden, although few holes were drilled to test this possibility. The absence of deeply buried deposits has not been completely proved by the studies in the 
district, but the geologic conditions, the generally negative results, and the small size of known deposits limits the likelihood of finding any, even if detailed drilling were done.

Deposits in the district range in size from a few feet to as much as 300 feet in greatest areal dimension and from less than a foot to about 30 feet in thickness; they include both bauxite and kaolin. The largest are in the $\mathrm{E} 1 / 2$ sec. $23, \mathrm{~T} .4 \mathrm{~S} .$, R. $15 \mathrm{~W}$. Ideally, bauxite occurs in the central part of a deposit and is surrounded by or grades into kaolin below and on all sides. This kaolin in turn grades into sandy kaolin and sand. The contacts may be abrupt. Inasmuch as nearly all deposits in the Margerum district are at or very close to the surface, most of the tops have been eroded and covered by slope wash, possibly in several cycles.

The bauxite deposits lie within the top of the Gordo Formation, and, as postulated by Bridge, the clay and bauxite developed on the eroded surface of the formation during Paleocene and Eocene time and in part have formed from "a thin sequence of alluvial materials deposited on this ancient erosion surface" (Bridge, 1950, p. 187). Preservation of the deposits is probably due to their deposition in sinkholes formed in the underlying limestones.

The uniformly low grade of deposits in the district may indicate considerable resilication, rather than originally poor material. This view may be supported by (1) the high proportion of pisolitic kaolin to pisolitic bauxite in most deposits, the bauxite forming the core of the deposit, (2) the small size of deposits, which would permit complete penetration by siliceous waters, (3) a pisolitic texture which is more permeable than massive clay, (4) and an environment of siliceous and sandy formations. Reworking and redeposition of the deposits and the consequent mixing of sand and clay with original bauxite also undoubtedly occurred and is reflected in the clayey matrix of many deposits.

The bauxite is generally rather soft and pisolitic. It appears to harden on exposure, for most pisolitic float is rather hard and characteristically has empty pisolites. Bauxite is white to tan but may be in part rusty to dark red and brown. Most pisolites show only rudely concentric structures. Compound pisolites are not uncommon.

The first bauxite discovered in Colbert County was a small deposit found by J. W. Adams in 1921. It is exposed east of the road at a gravel pit north of the mapped area approximately a quarter of a mile south of Margerum at the east edge NE1/4 sec. 35, T. 3 S., R. 15 W. The deposit is nested in an east-trending remnant of gravel of the Gordo Formation within the outcrop area of the Ste. Genevieve Limestone equivalent. The bauxite is soft, brown, and crudely pisolitic 
and is relatively high in iron. The deposit is too small to be of more than scientific interest. X-ray analyses of two samples showed more gibbsite than kaolinite in one, and kaolinite with some quartz but no gibbsite in the other. No chemical analyses are available. No other lenses are known in the vicinity.

South of the first discovered deposit and about 4 to 5 miles south of Margerum are several lenses and numerous pockets of bauxite and kaolin within an area $11 / 4$ miles long and about half a mile wide in the E1/2 sec. 23, NW1/4 sec. 24 , SE1/4 sec. 14 , and SW1/4 sec. 13 , T. 4 S., R. $15 \mathrm{~W}$. Most of these were discovered by Adams between 1921 and 1925. The geologic studies and drilling program in 1942 and 1943 permitted certain limits of the deposits to be defined and resources to be evaluated.

\section{CLASSIFICATION}

The Thoenen-Burchard classification $(1941$, p. 38) is used to designate grades of bauxite. This classification is as follows:

\begin{tabular}{|c|c|c|}
\hline Grade & $\begin{array}{c}\text { Alumina } \\
\text { (percent) }\end{array}$ & Silica (percent \\
\hline 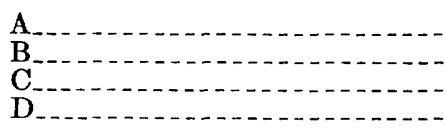 & $\begin{array}{r}+55 \\
50-55 \\
45-50 \\
30-45\end{array}$ & $\begin{array}{l}\text { Less than } 7 . \\
\text { Less than } 15 . \\
\text { Less than } 30 \text {. } \\
\text { High in silica and iron. }\end{array}$ \\
\hline
\end{tabular}

According to this classification, most of the material discovered in the Margerum district is of grade D quality. As can be deduced from the chart, part of grade D (45 percent alumina) includes material that, depending on the iron and silica content, may contain a considerable amount of gibbsite; but the lower limit of grade D (30 percent alumina) generally allows enough silica to form kaolinite or even a sandy kaolin. In this paper, the part of grade $\mathrm{D}$ in which the percentage of alumina exceeds the percentage of silica is called bauxite, and the part in which alumina is less than silica is called kaolin.

Unanalyzed material that is pisolitic is called bauxite or bauxitic clay, but unanalyzed smooth-textured material is called kaolin, kaolinitic clay, or sandy clay, depending on the apparent quality. However, texture and appearance are not reliable indicators of the gibbsitekaolinite ratio, and chemical or other analysis is requisite for proper identification.

Most pisolitic material in the Margerum district has a chemical composition close to that of kaolinite and is called pisolitic kaolin. The presence of a high proportion of pisolitic kaolin grading into bauxite in the inner parts of the deposits suggests that resilication of deposits, 
originally more gibbsitic, has been a dominant process in the district since the formation of the deposits.

\section{DRILLING PROGRAM}

The U.S. Geological Survey and the U.S. Bureau of Mines conducted a brief joint drilling program in the district in the hope of finding bauxite of commercial grade and in sufficient quantity to warrant development. Some chemical analyses of bauxite from old test pits indicated ore assignable to grade $\mathrm{C}$ of the classification proposed by Thoenen and Burchard (1941, p. 38). The drilling program was designed to test the possibility of extension of the known small deposits under cover and the possibility of lower iron and silica content.

In the original drilling plan, the senior author recommended that 40 holes, spaced approximately 400 feet apart, be drilled in the areas considered especially favorable for prospecting and that 14 wildcat holes be drilled in the region immediately east and south of the known bauxite area. A churn-drill rig operated by the Pennsylvania Drilling Co. of Pittsburgh, Pa., under contract with the U.S. Bureau of Mines, began work on May 28. Most of the drilling was by drive pipe, although a churn drill was used in gravel and ferruginous conglomerate. After 6 holes were drilled, it became apparent that the small size of the deposits and their random location precluded this method of prospecting; the original spacing was abandoned, and tests were made only in areas showing pisolitic clay float along the surface slopes. Some holes were drilled adjacent to old pits. Thirty-seven holes having a total footage of 2,446 feet were drilled and were logged by the senior author. Thirty-eight shallow hand-auger holes were also sunk to determine the extent of the larger clay bodies. Because of the poor results obtained from drilling near the known deposits, no further wildcat drilling was done, and the project was closed July 30, 1943. A report on the joint program by D. M. Coulter (1948) of the U.S. Bureau of Mines shows the location of drill holes and includes chemical analyses of cored intervals and of samples from some of Adams' test pits.

\section{INDIVIDUAL DEPOSITS}

The individual bauxite and kaolin deposits and their immediate vicinity are discussed as separate areas which are designated by letter, and pits and test holes are indicated by number and symbol on plate 2 . Designations used by Coulter (1948, p. 6-10 and fig. 3) for the individual areas in the district are compared with those used in this report as follows: 


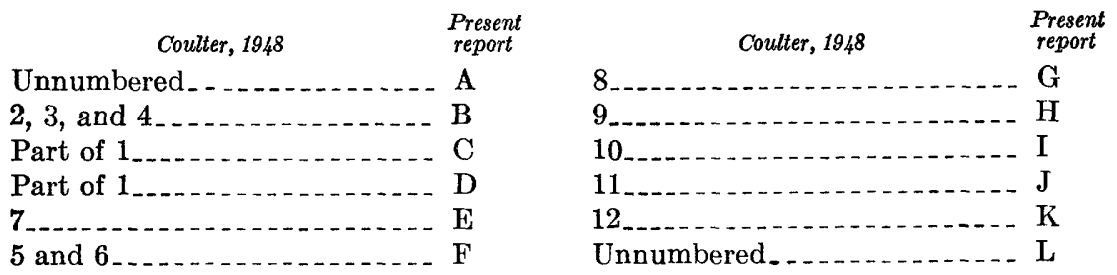

Holes drilled in the joint program are numbered 1 through 37 and 101 through 134; those numbered below 100 were churn-drill holes, and those numbered over 100 were hand-auger holes. All the pits and trenches were dug during the early 1920 's by J. W. Adams. These are numbered consecutively, irrespective of whether they are pits or trenches. Chemical analyses, unless otherwise indicated, were made in the Bureau of Mines Laboratory in Tuscaloosa, Ala.

AREA A

Area $A$ is largely in the $\mathrm{SE}_{1} 1 / 4 \mathrm{SW}_{1 / 4} \mathrm{SE}^{1 / 4}$ and $\mathrm{SW}_{1} 1 / 4 \mathrm{SE} 1 / 4 \mathrm{SE} 1 / 4$ sec. 14, T. 4 S., R. 15 E. but extends a short distance south into sec. 23, (pl. 2). A small deposit of bauxite and sandy kaolin is exposed in test pits 50 and 51. Sandy pisolitic clay boulders and cobbles are scattered along the slope a few yards to the south, but hand-auger holes 108, 109, and 110, drilled south and southeast of the pits, did not penetrate additional bauxite or kaolin. The deposit seems to be cut out on the north by a ferruginous conglomerate and to be limited on the west by the sandy nonpisolitic clay found in pit 51.

Pisolitic float can also be seen in a few places north of the lens. Test pits 48 and 52 penetrated thin beds of sandy pisolitic clay, but these beds are considered to be separate from the deposit discovered in pit 50 and probably represent an accumulation downhill of reworked material.

At pit 50 pisolitic bauxite crops out at the surface and extends to a depth of 27 feet. Chemical analyses, in percent, of two samples from about midway in depth are cited by Jones (1940, p. 87) as follows:

$\begin{array}{cccc}\mathrm{Al}_{2} \mathrm{O}_{3} & \mathrm{SiO}_{3} & \mathrm{Fe}_{2} \mathrm{O}_{3} & \text { Ignition loss } \\ 45.33 & 22.64 & 3.71 & 29.00 \\ 43.00 & 35.00 & 3.14 & 16.64\end{array}$

AREA B

A relatively large and somewhat irregular area in adjacent parts of secs. 13, 14, and 24, T. 4 S., R. 15 W. is designated area B. Adams dug many pits along the ridge and the slope south of Calhoun Hollow (pl. 2), and pisolitic bauxite and kaolin were found in most of them. Studies during the drilling program, however, demonstrated that two small deposits and several pocketlike lenses nest in sand and gravel 
but are not parts of a single large body. The two small deposits are among the highest in grade in the Margerum district.

Two of Adams' test pits, Nos. 18 and 20, were in one of these deposits. According to a $\log$ cited by Jones $(1940$, p. 84 ), pit 18, the deeper, from top to bottom penetrated about 3 feet of a bauxite and clay mixture, 31 feet of bauxite, and 4.6 feet of sand below the bauxite. The 31 feet of bauxite consists of two lenses of grade C bauxite separated by and underlain by grade $\mathrm{D}$. The grade $\mathrm{C}$ bauxite in both lenses aggregates about 18 feet in thickness. Of this, the uppermost 6 feet averaged grade $\mathrm{B}$ on the basis of alumina content alone but was about $1 \frac{1}{2}$ percent too high in silica to be so considered. Pit 20, about 30 feet northeast of pit 18, was in bauxite from a depth of 2 to 13 feet, the bottom of the pit. Two samples from this pit were analyzed, but the exact depths at which they were taken is unknown. The upper sample is a true grade B bauxite. The lower one is grade D. Chemical analyses of samples from the pits are as follows:

\begin{tabular}{|c|c|c|c|c|c|c|}
\hline \multicolumn{2}{|c|}{ Depth (feet) } & \multicolumn{5}{|c|}{ Analyses (percent) } \\
\hline From & To & $\mathrm{Al}_{2} \mathrm{O}_{3}$ & $\mathrm{SiO}_{2}$ & $\mathrm{Fe}_{2} \mathrm{O}_{3}$ & $\mathrm{TiO}_{2}$ & $\begin{array}{c}\text { Ignition } \\
\text { loss }\end{array}$ \\
\hline \multicolumn{7}{|c|}{ Pit 181} \\
\hline $\begin{array}{r}4 \\
6 \\
10 \\
16 \\
22 \\
28\end{array}$ & $\begin{array}{r}6 \\
10 \\
16 \\
22 \\
28 \\
31\end{array}$ & $\begin{array}{l}52.4 \\
52.8 \\
47.6 \\
41.0 \\
50.0 \\
37.2\end{array}$ & $\begin{array}{l}16.4 \\
16.5 \\
23.9 \\
39.3 \\
21.5 \\
41.2\end{array}$ & $\begin{array}{l}2.9 \\
2.8 \\
4.6 \\
2.2 \\
2.8 \\
5.9\end{array}$ & $\begin{array}{l}2.5 \\
2.4 \\
2.2 \\
2.0 \\
2.2 \\
1.4\end{array}$ & $\begin{array}{l}25.8 \\
25.5 \\
21.7 \\
15.5 \\
23.5 \\
14.3\end{array}$ \\
\hline \multicolumn{7}{|c|}{ Pit $20^{2}$} \\
\hline 2 & $1 \overline{1}$ & $\begin{array}{l}54.82 \\
47.00\end{array}$ & $\begin{array}{l}14.34 \\
21.00\end{array}$ & $\begin{array}{l}3.42 \\
5.00\end{array}$ & & $\begin{array}{l}\text { 25. } 80 \\
\text { 25. } 00\end{array}$ \\
\hline
\end{tabular}

1 Analyses made by Tennessee Valley Authority cited by Coulter $(1948$, p. 6).

2 Analyses from Jones (1940, p. 85).

The bauxite in the deposit is characteristically soft and white and consists largely of pisolites and very little matrix.

Three churn-drill holes, Nos. 8, 9, and 10, were put down during the Federal project to test the deposit for extensions uphill. Each penetrated only sand and gravel containing silty or sandy clay zones. Pits dug by Adams north and east of the deposit penetrated sand and gravel containing some reworked bauxite but no extension of the deposit.

The second small deposit in area B is about 200 feet south-southwest of the one just described (pl.2). Adams dug five pits (4, 7, 10, 12, and 
14) and one trench (6) in and around this deposit. The bauxite penetrated by pits 12 and 14 almost certainly is part of a continuous deposit, but that in pit 7 is at a higher altitude and may represent a separate small lens. The bauxite in pit 7 is shown in trench 6 to be underlain by sand at the altitude of the bauxite in pits 12 and 14 . The bauxite in pit 4, on the other hand, is at a lower altitude than the bauxite in the two main pits (12 and 14). If all four pits $(4,7,12$, and 14) are in a single deposit, the deposit extends downhill and is thickest in the middle. As the evidence, however, does not suggest this interpretation, three separate deposits are considered to exist at the present time, although they may once have been part of a single large deposit. No holes were drilled here, as the deposit seemed to be sufficiently delimited by the pits and trench, and chemical analyses were available. These analyses are reported by Jones (1940, p. 83 and $84)$.

A small lens of bauxite was also penetrated by Adams' pit 28. The pit revealed 4 feet of overburden and 3.6 feet of slightly bauxitic clay for a total depth of 7.6 feet. A sample taken from the bottom of the pit contained 45.07 percent alumina and 33.96 percent silica (Jones, 1940, p. 85).

Pisolitic material found in the remainder of the pits and drill holes had the chemical composition of sandy kaolin, slightly ferruginous kaolin, or low-grade bauxite. None of these occurrences seems to have an areal extent or depth of more than a few feet; each pit or hole seems to be in a separate deposit.

\section{AREA C}

A deposit of pisolitic kaolin and bauxite about 300 feet long and at least 100 feet wide at the widest place lies at or within a foot of the surface on a south-facing slope (S1/2 NW1/4 NE1/4 NE1/4 sec. $23, \mathrm{~T}$. $4 \mathrm{~S} ., \mathrm{R} .15 \mathrm{~W}$.) south of the main ridge trail (pl. 2). Test pit 54 and trench 56 dug by Adams and hand-auger holes 103 and 104 penetrated the deposit. Isopachs drawn on thickness of kaolin plus the bauxitic material and sandy kaolin assumed to be present are shown on plate 3. The locations of all exploratory openings are also shown. The north boundary of the deposit is drawn as an arbitrary straight line because of lack of data in that direction. The deposit is considered to extend about 50 feet west of hole 104 on the basis of about 10 feet of very sandy pisolitic clay found in hole 1 , and it extends about 25 feet east of hole 103. The south limits are more or less defined by the slope of the ground surface.

Chemical analyses show the highest alumina contents to be several percent higher than the amount that would be required to form kaolinite if all of the silica were so used, but the deposit also includes piso- 
litic material that is sandy. Analyses for holes 103 and 104 are given by Coulter (1948, p. 6) and for pit 54 by Jones (1940, p. 88).

Section $A-A^{\prime}$ (pl. 3) shows the general shape of the deposit. Holes 104 and 103 penetrated sand and gravel beneath kaolin. Overburden is about 1 foot thick and consists of surface soil and colluvium.

Hole 3, south of the deposit, penetrated 18 feet of clay at a depth of 23 to 41 feet, below sandy clay. Analyses of four samples from this interval averaged 31.8 percent alumina and 52.5 percent silica. Apparently the clay forms a small pocket in sand and gravel but is not connected with the main deposit. Heavy conglomerate is exposed on the intervening slope.

Pisolitic material or good kaolin was not found in any of the other holes in the area, except for a thin bed of very sandy pisolitic clay in hole 106.

\section{AREA D}

A very small body of pisolitic kaolin or clay-ball conglomerate crops out on a west-facing slope about 200 feet west of a ridge trail in the NW $1 / 4$ SE $1 / 4$ NE $1 / 4$ NE $1 / 4$ sec. 23, T. 4 S., R. 15 W. (pl. 2). Two pits, Nos. 58 and 62 , and a trench, No. 60, were dug by Adams, and two holes, Nos. 101 and 111, were drilled during the Federal project in the area. Adams apparently thought the deposit was of little commercial value because his pits are only 5 and 10 feet deep and he had no chemical analyses made of the material. Hole 101 went through 3 feet of pisolitic clay below a depth of 3 feet. This clay was underlain by sand and gravel from 6 to 11 feet and impure sandy clay between 11 and 22 feet; the bottom of the hole was in clay and gravel. Chemical analysis of the "bauxite" interval showed a sandy clay containing 34.9 percent alumina, 48.3 percent silica, 2.6 percent iron oxide, 1.8 percent titania, and 13.0 percent loss on ignition (Coulter, 1948, p. 6). Hole 111, which delimits the deposit on the south, penetrated only sand and clay to a total depth of 11 feet.

\section{AREA E}

A deposit of somewhat bauxitic clay was found during the drilling project in area $\mathbf{E}$ along the ridge and the west-facing slope approximately 175 feet north of the abandoned Twitty tenant house (pl.2). It lies in the SW. cor. SE $1 / 4 \mathrm{NE}^{1} / 4 \mathrm{NE} 1 / 4$ and the N1/2NW1/4 SE $1 / 4 \mathrm{NE} 1 / 4$ sec. 23, T. 4 S., R. 15 W. Pisolitic nodules are scattered over the surface west of the trail to the tenant house.

Holes 19, 20, 112, 114, and 115 were drilled in the deposit. Clay was found within 2 to 3 feet of the surface and was overlain by soil or sandy clay in all holes except 115. At hole 115 the gravel overburden was 8 feet thick. The deposit is long and narrow, elongate to the northwest (pl. 3), and thickest at the southeast end, where hole 
20 penetrated 47 feet of kaolin, in part bauxitic. The southeastern part of the deposit is delimited on the east and west by indurated bodies of heavy conglomerate and on the east also by a shallow valley. Sufficient holes were not drilled to accurately delimit the body because of its low grade. A somewhat generalized section through the deposit is shown on plate $3, B-B^{\prime}$. At the south end the kaolin appears to fill a sinkhole. The thickness of the sand and gravel unit shown in the section is unknown, but residuum from the underlying Mississippian rocks may have been reached in the bottom of hole 20 .

The only material which was found by drilling in area $\mathbf{E}$ and which contained more alumina than silica was from a depth of 5 to 10 feet in hole 20. Chemical analyses of samples from a depth of 10 to 24 feet in this hole and from a depth of 7 to 9 feet in hole 19 were that of only slightly bauxitic clay. Chemical analyses of core or cuttings obtained from the remainder of the deposit approximated that of kaolin, or ferruginous or sandy kaolin. Chemical analyses of samples from holes 19 and 20 are given by Coulter $(1948$, p. 7$)$.

The lithologic units in hole 20 were logged as follows: 3 to 45 feetclay, yellow to red, pisolitic; 45 to 52 feet-clay, tan to red and white, smooth-textured; 52 to 56 feet-clay, sandy; 56 to 75 feet--sand, brown, fine-grained; 75 to 80 feet-chert gravel. The last unit may be residual from the underlying rocks of Mississippian age, or it may represent gravel of the Gordo Formation.

\section{AREA F}

An irregular area, mostly in the SW1/4 NW1/4NW1/4 sec. 24, T. 4 S., R. $15 \mathrm{~W}$. (pl. 2), but extending somewhat to the south and east, is designated area F. Float and outcrops of sandy pisolitic material and clay-ball conglomerate can be seen at a number of places along the south side of the principal ridge and its spurs. Many small pockets of sandy clay or low-grade bauxite, close to or at the surface, and one larger deposit were discovered by Adams. His test pits 88,98, 100, and 102 and trenches 86 and 96 (pl. 2) penetrated some of the small pockets but holes $13,14,15$, and 16, drilled nearby, showed none to have a lateral extent or depth of more than a few feet. The only chemical analyses available of these deposits are of samples from the upper 16 feet in pit 100 (Jones, 1940, p. 94), which showed about 45 to 48 percent alumina and 28 to 30 percent silica, and from pit 88 at a depth of 3 to 5 feet (Coulter, 1948, p. 7), which showed 39.2 percent alumina and 33.6 percent silica.

The largest deposit in area $\mathrm{F}$ was prospected by $A$ dams, by means of pit 92 and trench 90 ; during the Federal project, hole 18 was drilled in the deposit. The exploration indicates a small deposit that is on a 
west-facing slope and now probably does not exceed 9,600 square feet in area. Bauxite and kaolin extend from a depth of 3 to 35 feet in hole 18 and from 4 to 30 feet in pit 92 . The lens once may have extended uphill to the east and thinned laterally to the vicinity of pits 94 and 95 where there is surface float of pisolitic clay. Such a deposit originally may have been somewhat similar in section to the one in area $\mathbf{E}$ (section $B-B^{\prime}$, pl. 3 ). If this supposition is true, erosion removed most of the clay or bauxite along the east margin and left only the thicker part to the west. Overburden on the deposit is negligible, in places amounting to a few feet of surface soil and sandy clay. Chemical analyses of samples from drill hole 18 are given by Coulter $(1948$, p. 7$)$ and from pit 92 by Jones (1940, p. 93).

\section{AREA G}

Pisolitic bauxite and kaolin in area $G$, in the $\mathrm{SE}^{1} / 4 \mathrm{SE}_{1} / 4 \mathrm{NE}_{1} 1 / 4$ sec. 23, T. 4 S., R. 15 W. (pl. 2), are exposed in shallow pits and trenches dug by Adams on the west-facing slope and the top of the hill between McCluskey Hollow and its main tributary to the north. Ten holes were drilled to delimit the deposit and study the geologic setting.

The bauxite and kaolin deposit in area $G$ is geologically one of the most interesting in the Margerum district. Lignitic clay and a thick sequence of fine sand are associated with the bauxite and clay in an ancient sinkhole. The Bethel Sandstone crops out about 500 feet above sea level along the valley of the north branch of McCluskey Hollow, but deep drill holes 24 and 25 in the deposit (pl. 3) penetrated lignitic clays, pisolitic bauxite and kaolin, smooth clay, and fine sand to a depth of more than 100 feet. Thus, rocks of Mississippian age under the deposit must be at least 80 feet below the outcrop of the Bethel Sandstone just north of the deposit (near C, pl. 3). As none of the drill holes penetrated indurated rock of Mississippian age, the sinkhole shown in section $C-C^{\prime}$, plate 3 , is partly inferred. Four deep holes, however, stopped in sand or chert gravel beneath sand at the following depths: Hole 24, at 107 feet; hole 25, at 103 feet; hole 26, at 80 feet; and hole 27 , at 65 feet; this information indicates a relatively large and deep sinkhole. The abrupt lateral changes in lithology throughout the deposit and differences in materials at the same altitude in adjacent drill holes suggest an area of coalescing sinks and intermittent deepening during deposition of the Tertiary sediments. Coarse gravel of the Gordo Formation, in places indurated, covers the surface between the main deposit and the small one to the east (pl. 3). The gravel does not seem to be a mere surface wash but is believed to be the Gordo Formation in place and to indicate that the small body fills a separate sinkhole. Hole 25 is thought to be in a quasi-independent sink which contains smooth kaolin that is unlike clays in the 
main body but which contains no bauxite. Lignite in hole 25 is beneath the kaolin, but in the remainder of the area, where present, it is above or younger than the bauxitic material. Brown sand, similar to that in hole 24 , is present beneath the clay in hole 25 , a fact suggesting a considerable time span in the formation of these sinkhole fillings.

The bauxite and kaolin deposit seems to be very irregular in thickness and areal extent as well as in grade of material. Most of the pisolitic material exposed in the pits, trench 64 , or in drill holes has a chemical composition similar to kaolin or sandy kaolin; little of it contains more alumina than silica; and none of it is high enough in grade to be attractive commercially. Slightly bauxite material was found scattered here and there throughout the deposit except for the northern extension, represented only by core from hole 24. Hole 24 penetrated sandy pisolitic "bauxite" containing streaks of clay, ferruginous clay, or scattered sand, from a depth of 55 to 79 feet. The lithology indicates a considerable reworking, as might be expected from its depth in relation to the main body as shown on section $C-C^{\prime}$, plate 3. Bauxite was found in pits 66,67, and $68 \mathrm{dug}$ by Adams and in drill holes 27 and 117. The highest grade sampled was from pit 66 (about 55 percent alumina and 26 percent silica) and the next highest, from hole 117. Kaolin or sandy kaolin was found in the holes and pits containing bauxite and in trench 64 , pit 70, and holes 24,119 , and 120. Part of the kaolin was pisolitic.

Analyses of samples from Adams' pits 66 and 67 are given by Jones (1940, p. 89). Analyses for holes 24, 27, 117, 119, and 120 are given by Coulter (1948, p. 7-8).

Lignitic clay and lignite fragments logged in four holes were not examined for spores and did not contain macroscopic plant impressions. The cores are no longer available. Lignitic clay, about 20 to 30 feet thick, was found in holes 24 and 25 , and fragments of lignite in thin beds were found in the upper parts of holes 26 and 27 . In hole 27 the lignite fragments are mixed with material in the top of the bauxite bed which appears to be reworked, but elsewhere the lignitic material overlies pisolitic kaolin or bauxite. Lignite is characteristic of the Wilcox Group of early Eocene age throughout eastern United States, and the position of lignitic clay with respect to pisolitic material in the Margerum district is the same relation as the lignite of Wilcox age and the pisolitic material of early Eocene or Paleocene age elsewhere in the southeast.

\section{AREA H}

Sandy pisolitic clay nodules are scattered over parts of the surface near the wagon road on the ridge between McCluskey and Harris Hollows in area $\mathrm{H}\left(\mathrm{SW}_{1} 1 / 4 \mathrm{NE}^{1 / 4} \mathrm{SE} 1 / 4\right.$ and $\mathrm{SE} 1 / 4 \mathrm{NW}_{1} 1 / 4 \mathrm{SE} 1 / 4$ sec. 23 , 
T. 4 S., R. 15 W.) (pl. 2). Area $\mathrm{H}$ is on a gentle slope. A bauxite and kaolin deposit here was first prospected by Adams who dug one trench and three shallow test pits. Six holes were drilled during the Federal investigation.

A small deposit of pisolitic bauxite and kaolin was shown by the exploratory openings. The deposit is elongate to the northwest and is simple in section (section $D-D^{\prime}$, pl. 3). Like other deposits in the Margerum district, this deposit is underlain by an indeterminate thickness of fine sand. One hole penetrated a buff-colored clay which contained small fragments of black lignitic clay and which overlay the pisolitic material (section $D-D^{\prime}$, pl. 3). This sequence is similar to that in area $G$.

Chemical analyses of samples from Adams' pit 79 and from drill holes 36,132 , and 133 indicate that the deposit is primarily of kaolin generally containing a very minor amount of gibbsite. The only samples in which the percent of alumina exceeded the percent of silica were from the upper part of hole 36. This material, the highest grade known in area $H$, is grade $D$ bauxite. Analyses of samples from Adams' pit 79 have been published by Jones (1940, p. 91) and for drill holes 36,132 , and 133 by Coulter $(1948$, p. 8$)$.

Trench 78, outside the deposit, has been cited (Jones, 1940, p. 91) as containing "good ore," but examination during the course of the drilling program showed only a sandy clay.

Outside of area $\mathrm{H}$ and approximately 400 feet southwest of the deposit, sandy pisolitic clay is exposed in the walls of pit $84(\mathrm{SE} 1 / 4 \mathrm{SE} 1 / 4$ $\mathrm{NW}_{1} / 4 \mathrm{SE} 1 / 4$ sec. 23) (pl. 2). There is no other showing of clay in the immediate vicinity of the pit.

\section{AREA I}

The largest known bauxite and kaolin deposit in the Margerum district is in area $I$, principally in the $W 1 / 2 \mathrm{SE}_{1} / 4 \mathrm{NE}_{1} / 4 \mathrm{SE} 1 / 4$ and E $1 / 2$ SW $1 / 4$ NE $1 / 4$ SE $1 / 4$ sec. 23, T. 4 S., R. 15 W., but extending southward into adjacent quarter-quarter-quarter sections. The deposit lies near the surface on an irregular east-facing slope and a flat just south of an old wagon trail (pl. 2). Two test pits had been dug in the deposit by Adams, and during the Federal drilling program 11 holes were drilled to delimit the body.

The northern part of the deposit seems to be a large, rather symmetrical lens about 300 feet long, 250 feet wide, and at least 40 feet thick in the central part (pl. 3), but the southern part is irregular in shape and is represented by arbitrary cutoff on three sides because of incomplete data.

The bauxite and clay are gray to tan or red. The lighter colored material commonly has a mottled appearance due to secondary iron 
oxide staining. The bauxite and clay are both pisolitic, but the pisolites are not abundant.

The highest grade bauxite reported came from Adams' pit 75. Analyses made for Adams are cited by Jones (1940, p. 90); the two most aluminous samples are grade $\mathrm{C}$ bauxite which had the following composition :

\begin{tabular}{l|c|c|c|c|c}
\hline \multicolumn{2}{c|}{ Depth (feet) } & \multicolumn{4}{|c}{ Analyses (percent) } \\
\cline { 1 - 4 } From & To & $\mathrm{Al}_{2} \mathrm{O}_{3}$ & $\mathrm{SiO}_{2}$ & $\mathrm{Fe}_{2} \mathrm{O}_{3}$ & Ignition loss \\
\hline 13.4 & 17 & $\begin{array}{l}49.26 \\
48.60\end{array}$ & $\begin{array}{l}26.80 \\
26.00\end{array}$ & $\begin{array}{l}3.71 \\
5.00\end{array}$ & $\begin{array}{l}19.28 \\
20.20\end{array}$ \\
\hline
\end{tabular}

No samples collected during the joint drilling program, even from pit 75 , were high enough in alumina to be classed as grade $\mathrm{C}$.

The highest grade discovered was in hole 125 and pit 75 in the thickest part of the deposit (section $E-E^{\prime}, \mathrm{pl} .3$ ). The entire depth penetrated by each was bauxitic, except for the uppermost several feet. The deposit thins in all directions from these two openings and grades into kaolin. Samples from a 5-foot interval in hole 30, a 13-foot interval in hole 127 , and a 10 -foot interval in hole 126, adjacent to the bauxitic central part, contained only a little more alumina than is requisite for the formula for kaolinite. The bottom 8 -foot interval in hole 130 in the southern part of the deposit was also bauxitic. In these four holes both bauxite and nonbauxitic clays were penetrated, but elsewhere in the deposit only kaolin or sandy or silty kaolin was present.

Chemical analyses of samples from the two openings which contained the highest grade bauxite and from an adjacent hole which penetrated both bauxite and kaolin are given by Coulter (1948, p. $9-10)$.

\section{AREA J}

The small bauxite and kaolin lens in area $\mathrm{J}\left(\mathrm{E} 1 / 2 \mathrm{SE} 1 / 4 \mathrm{NE}_{1} / 4 \mathrm{SE}^{1 / 4}\right.$ sec. 23, T. 4 S., R. 15 W.) is the only deposit in the Margerum district which has been mined. A small pit was opened in May 1943 by the Tennessee Valley Authority, and 30 tons of light-colored pisolitic bauxite was mined and shipped to the TVA plant at Wilson Dam. The ore was used in experiments in the manufacture of aluminumsilicon alloys.

The deposit at area $J$ was discovered in the 1920's by Adams who dug one test pit, No. 74, near the center of the deposit. Eight holes were drilled during the joint project to delimit the deposit and to test for an extension to the north. The location of five of the holes and 
pit 74 are shown on plate 2 . The remaining three holes were unnumbered, shallow hand-auger holes in bauxite at 50,90, and 100 feet north of the TVA pit.

Exploration indicates that the deposit is limited to an area about 90 feet east-west and 75 feet north-south and that it is thickest and highest grade near the middle. Toward the margins, the deposit consists only of kaolin.

Variations in the bauxite can be seen in the TVA pit. Here brownweathered clay caps red-mottled pisolitic bauxite and is conspicuous along joints in the bauxite. Compound pisolites are common in the highly pisolitic western part of the deposit, but the number of pisolites and their hardness decrease toward the east end of the pit, where only a very few are found in a buff clay containing lignite fragments.

Chemical analyses made for Adams of samples from his pit 74 and analyses from auger hole 123 show some of the variation in grade outward from the center, although later analyses (Coulter, 1948, p. 10) of samples from Adams' pit failed to show as high a grade. The analyses are as follows:

\begin{tabular}{|c|c|c|c|c|c|c|}
\hline \multicolumn{2}{|c|}{ Depth (feet) } & \multicolumn{5}{|c|}{ Analyses (percent) } \\
\hline From & To & $\mathrm{Al}_{2} \mathrm{O}_{3}$ & $\mathrm{SiO}_{2}$ & $\mathrm{Fe}_{2} \mathrm{O}_{3}$ & TiO, & $\begin{array}{l}\text { Ignition } \\
\text { loss }\end{array}$ \\
\hline \multicolumn{7}{|c|}{ Pit 74 1} \\
\hline 3 & $1 \overline{3}$ & $\begin{array}{l}52.86 \\
53.68\end{array}$ & $\begin{array}{l}20.58 \\
21.08\end{array}$ & $\begin{array}{l}1.50 \\
1.60\end{array}$ & 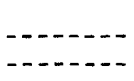 & $\begin{array}{l}24.64 \\
21.08\end{array}$ \\
\hline \multicolumn{7}{|c|}{ Drill hole 123 : } \\
\hline 4 & 10 & 35.9 & 46.1 & 2.0 & 1.8 & 13.3 \\
\hline
\end{tabular}

1 Analyses from Jones $(1940$, p. 89).

2 Analyses from Coulter (1948, p. 10).

\section{AREA $\mathbf{K}$}

A small bauxite and kaolin deposit in area $\mathrm{K}(\mathrm{SE} 1 / 4 \mathrm{NW} 1 / 4 \mathrm{SE} 1 / 4$ $\mathrm{SE} 1 / 4 \mathrm{sec} .23)$ is close to the surface in a flat just south of a wagon trail (pl. 2). The deposit is elongate to the northeast and is probably about 175 feet long and 75 feet wide. It has a maximum thickness of about 12 feet.

Two pits (Nos. 81 and 83) were dug by Adams, and one powerauger hole (No. 34) was drilled during the Federal project in this deposit. The power-auger hole penetrated tan silty clay containing lignite fragments and a few pebbles, from a depth of 4 to 8 feet. The clay overlaid 12 feet of sparsely pisolitic gray very slightly bauxitic clay, which in turn overlaid white to tan sand. "Rock" was struck 
at a depth of 35 feet in the hole. The sequence of clay containing lignite fragments, pisolitic bauxite, and sand is similar to the sequence found in the deposits in area $\mathrm{G}$ and area $\mathrm{H}$.

Chemical analyses show bauxite from Adams' pit 83, in the central part of the deposit, to be higher in grade than that obtained from hole 34 near the northeast end. Available analyses are as follows:

\begin{tabular}{|c|c|c|c|c|c|c|}
\hline \multicolumn{2}{|c|}{ Depth (feet) } & \multicolumn{5}{|c|}{ Analyses (percent) } \\
\hline From & To & $\mathrm{Al}_{3} \mathrm{O}_{3}$ & $\mathrm{SiO}_{2}$ & $\mathrm{Fe}_{2} \mathrm{O}_{3}$ & TiO, & $\begin{array}{l}\text { Ignition } \\
\text { loss }\end{array}$ \\
\hline \multicolumn{7}{|c|}{ Pit 831} \\
\hline 3 & 8 & 42. 79 & 37.12 & 2.57 & & 16. 16 \\
\hline \multicolumn{7}{|c|}{ Hole $34^{2}$} \\
\hline $\begin{array}{r}8 \\
15\end{array}$ & $\begin{array}{l}15 \\
20\end{array}$ & $\begin{array}{l}39.8 \\
38.8\end{array}$ & $\begin{array}{l}43.0 \\
43.3\end{array}$ & $\begin{array}{l}\text { 1. } 8 \\
\text { 1. } 7\end{array}$ & $\begin{array}{l}1.6 \\
1.5\end{array}$ & $\begin{array}{l}\text { 14. } 7 \\
14.1\end{array}$ \\
\hline
\end{tabular}

1 Analyses from Jones (1940, p. 91-92).

Analyses from Coulter (1948, p. 10).

AREA I

A small deposit of pisolitic clay in area $\mathrm{L}$ near the north end of a spur north of Harris Hollow (W1/2 $\mathrm{SE}_{1} / 4 \mathrm{SE}_{1} / 4 \mathrm{SE} 1 / 4 \mathrm{sec} 23, \mathrm{~T} .4 \mathrm{~S} ., \mathrm{R} .15$ W.) (pl. 2) is exposed at the surface. Part of the deposit has been removed by erosion, but available data suggest present dimensions of 100 feet north-south by 70 feet east-west, with a maximum thickness of 29 feet near the middle.

Two pits were dug in the deposit by Adams. Pit 85 at the north end penetrated 7 feet of pisolitic clay, and pit 76 at the south end penetrated at least 10 feet of similar material. Power-auger hole 32 was put down in the area by the Federal project near the center of the deposit. This hole penetrated somewhat pisolitic gray clay containing thin lenses of tan clay from the surface to a depth of 29 feet. The upper 2 feet were rather sandy, in part due to surface wash, but the remainder also was slightly sandy. The pisolitic material was underlain by thin beds of tan sand, silty clay, and indurated siltstone to a depth of 47 feet; this sand, clay, and siltstone in turn was underlain by brown fine sand containing scattered chert gravel to a depth of 54 feet, the bottom of the hole. The sequence at this deposit is similar to that at other deposits in the district.

Chemical analyses of pisolitic material in hole 32, made by the U.S. Bureau of Mines, are as follows: 


\begin{tabular}{|c|c|c|c|c|c|c|}
\hline \multicolumn{2}{|c|}{ Depth (feet) } & \multicolumn{5}{|c|}{ Analyses (percent) } \\
\hline From & To & $\mathrm{Al}_{2} \mathrm{O}_{3}$ & $\mathrm{SiO}_{3}$ & $\mathrm{Fe}_{2} \mathrm{O}_{3}$ & $\mathrm{TiO}_{2}$ & Ignition loss \\
\hline $\begin{array}{r}2 \\
8 \\
13 \\
18 \\
23\end{array}$ & $\begin{array}{r}8 \\
13 \\
18 \\
23 \\
29\end{array}$ & $\begin{array}{l}35.5 \\
36.6 \\
37.4 \\
37.4 \\
35.0\end{array}$ & $\begin{array}{l}46.1 \\
45.7 \\
45.3 \\
44.2 \\
47.5\end{array}$ & $\begin{array}{r}2.6 \\
1.3 \\
1.8 \\
1.9 \\
.9\end{array}$ & $\begin{array}{l}1.6 \\
1.8 \\
1.9 \\
2.0 \\
1.8\end{array}$ & $\begin{array}{l}13.3 \\
13.5 \\
13.5 \\
13.7 \\
13.1\end{array}$ \\
\hline
\end{tabular}

A composite sample collected by Adams from a depth of 3 to 10 feet in pit 76 was the highest grade analyzed from this deposit. It contained 40.48 percent alumina, 42.08 percent silica, 0.85 percent iron oxide, and 13.00 percent loss on ignition (Jones, 1940, p. 90). Adams' analyses of samples from pit 85 are nearly the same as the foregoing. Inasmuch as titania was not determined for these samples, the alumina content is a little too high, and gibbsite in the deposit is probably negligible.

\section{BENEFICIATION TESTS}

Beneficiation tests were made by the U.S. Bureau of Mines laboratory on material taken from the old prospect pit 75 in area $I$ at the south end of the district; the material responded favorably to washing and flotation, permitting a fairly good recovery of the alumina in concentrates of Bayer grade. The tests are described by Coulter (1948, p. 5). Unfortunately, much of the material in the various clay deposits is lower in alumina and higher in silica than the sample tested. In area $I$ as a whole, the silica content of bauxitic material may average as much as 30 percent.

\section{CONCLUSIONS}

The cooperative investigations by the U.S. Geological Survey and U.S. Bureau of Mines of the Margerum bauxite district confirm the early prospecting by Adams and studies by Burchard (1925, p. 101) and Jones (1940, p. 78-94). In general, the deposits are kaolin and low-grade bauxite; they are small; and the area of their occurrence is small.

The bauxite and kaolin occur in numerous small pockets close to the surface. Bauxite and kaolin were not found in any of the drill holes which penetrated heavy gravel, and are not believed to occur beneath thick gravels of the Gordo Formation. Prospecting indicates that the individual deposits are small and erratic in distribution and mostly are high in both combined silica and in sand. Lateral gradations in composition within a few feet are common. The highest grade material discovered is grade B bauxite, but that has been found only in small 
amounts at one or two places. A small amount of grade $\mathrm{C}$ bauxite was discovered, but most of the material is classed as grade $\mathrm{D}$ bauxite and kaolin.

The largest deposit is in the south end of the district in area I. Mining this deposit would not be difficult, for it lies at the surface, and a minimum amount of stripping would be necessary. Some of the other clay deposits could also be readily mined should interest justify the development.

Reserves of bauxite and kaolin for the district as a whole probably amount to approximately 100,000 long tons, largely of grade D, but including less than 5 percent of grade $\mathrm{C}$ bauxite. Drilling indicates an additional 30,000 long tons of lower grade sandy kaolinitic clay.

\section{LITERATURE CITED}

Bergquist, H. R., 1943, Geologic map of the Margerum bauxite district, Colbert County, Ala.: U.S. Geol. Survey Prelim. map.

Bridge, Josiah, 1950, Bauxite deposits of the southeastern United States, in Snyder, F. G., Symposium on mineral resources of the southeastern United States: Knoxville, Univ. Tennessee Press, p. 170-201.

Burchard, E. F., 1925, Bauxite in northeastern Mississippi : U.S. Geol. Survey Bull. 750-G, p. 101-146.

Butts, Charles, 1926, The Paleozoic rocks of Alabama: Alabama Geol. Survey Spec. Rept. no. 14, p. 177-183.

Coulter, D. M., 1948, Margerum bauxite district, Colbert County, Alabama: U.S. Bur. Mines Rept. Inv. 4207, 10 p.

Fenneman, N. M., 1938, Physiography of eastern United States: New York, MeGraw-Hill Book Co., p. 414-427.

Jones, W. B., 1926, Mississippian-Cretaceous contact : Econ. Geology, v. 21, no. 8, p. 795-798.

1929, Summary report on the bauxite deposits of Alabama: Alabama Geol. Survey Circ. 7, $36 \mathrm{p}$.

1940, Bauxite deposits of Alabama : Alabama Geol. Surrey Bull. 47, 94 p.

Thoenen, J. R., and Burchard, E. F., 1941, Bauxite resources of the United States: U.S. Bur. Mines Rept. Inv. 3598, 42 p. 
